Prepared in cooperation with the U.S. Army Corps of Engineers, Memphis District

\title{
Bed-Sediment Sampling and Analysis for Physical and Chemical Properties of the Lower Mississippi River near Memphis, Tennessee
}

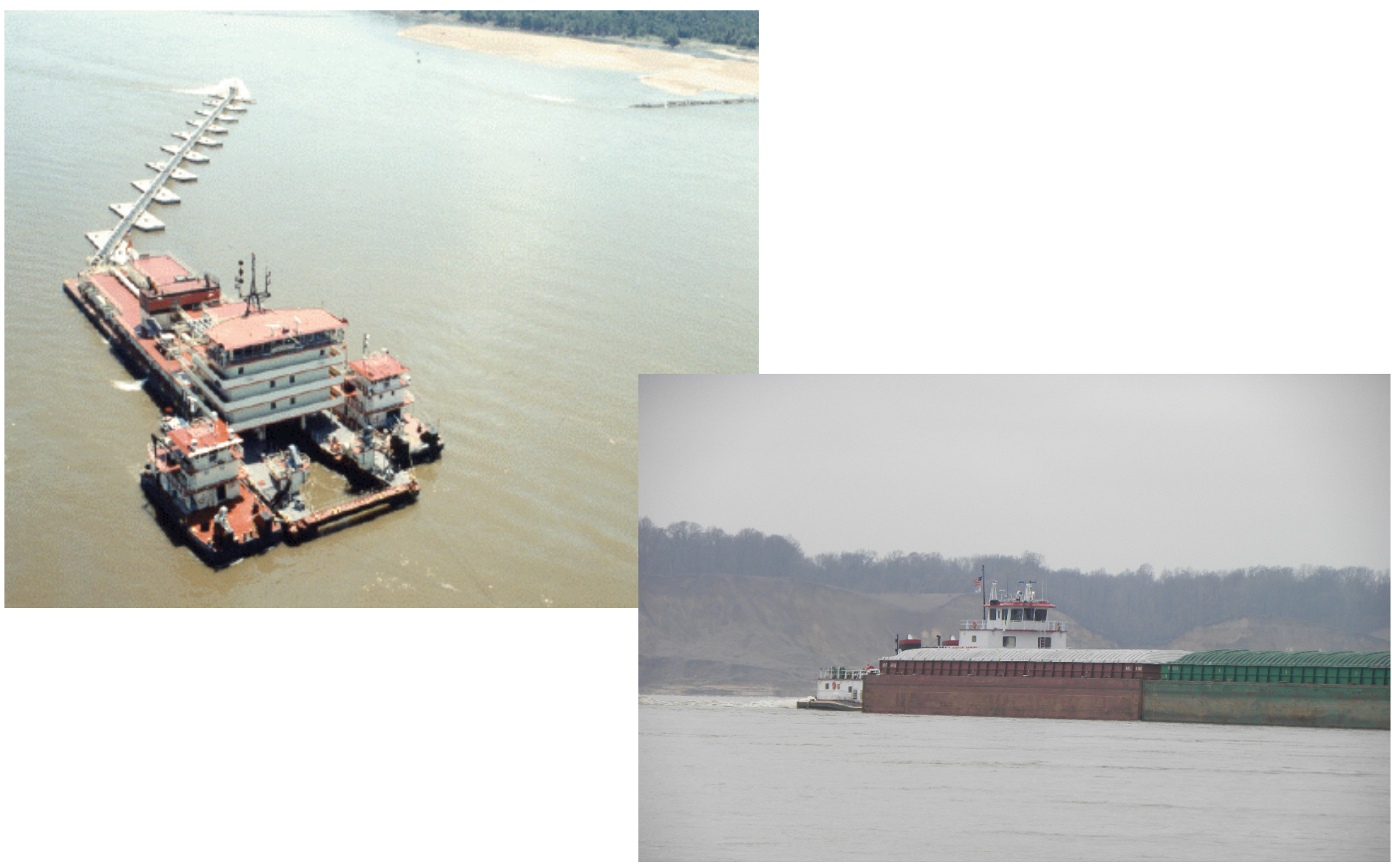

Open-File Report 2010-1113

U.S. Department of the Interior

U.S. Geological Survey 
Front cover. Left photograph - Dredger Hurley on lower Mississippi River near Memphis, Tennessee (Photograph by U.S. Army Corps of Engineers, Memphis District). Right photograph - Barge traffic on lower Mississippi River near Memphis, Tennessee (Photograph by Robert A. Blanchard, U.S. Geological Survey). 


\section{Bed-Sediment Sampling and Analysis for Physical and Chemical Properties of the Lower Mississippi River near Memphis, Tennessee}

By Robert A. Blanchard, Daniel M. Wagner, and Dennis A. Evans

Prepared in cooperation with the U.S. Army Corps of Engineers, Memphis District

Open-File Report 2010-1113 


\section{U.S. Department of the Interior \\ KEN SALAZAR, Secretary \\ U.S. Geological Survey \\ Marcia K. McNutt, Director}

U.S. Geological Survey, Reston, Virginia: 2010

This and other USGS information products are available at http://store.usgs.gov/
U.S. Geological Survey
Box 25286 , Denver Federal Center
Denver, CO 80225
To learn about the USGS and its information products visit http://www.usgs.gov/
1-888-ASK-USGS

Any use of trade, product, or firm names is for descriptive purposes only and does not imply endorsement by the U.S. Government.

Although this report is in the public domain, permission must be secured from the individual copyright owners to reproduce any copyrighted materials contained within this report.

Suggested citation:

Blanchard, R.A., Wagner, D.M., and Evans, D.A., 2010, Bed-sediment sampling and analysis for physical and chemical properties of the lower Mississippi River near Memphis, Tennessee: U.S. Geological Survey Open-File Report 2010$1113,22 \mathrm{p}$. 


\section{Contents}

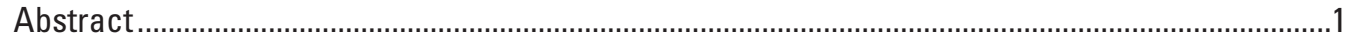

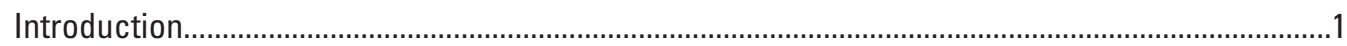

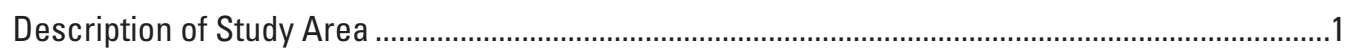

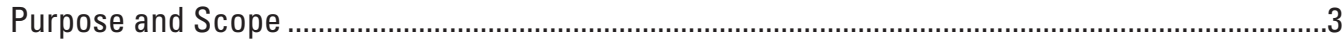

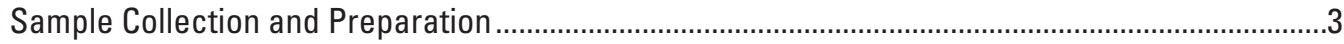

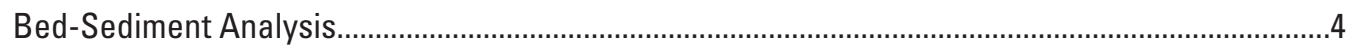

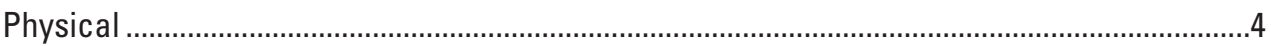

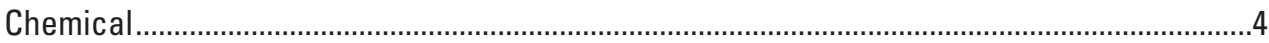

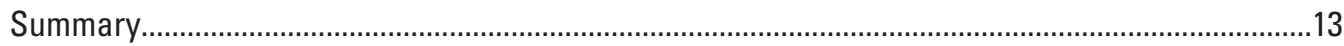

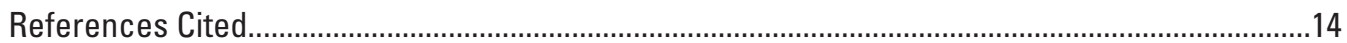

Appendix 1. Photographs showing sampling equipment, sampling methods and procedures, and bed-sediment samples ..................................................................................................16

Appendix 2. Chain of custody forms used by U.S. Geological Survey laboratories and TestAmerica Laboratory, Inc. ...........................................................................................21

\section{Figures}

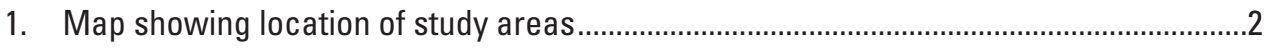

2. Photograph showing Shipek grab sampler .....................................................................

3. Photograph showing boom and winch system mounted on the deck of the T.E. Anderson sampling boat .3

\section{Tables}

1. Grain size analysis for bed-sediment samples collected on the Mississippi River ..........5

2. Analytical results for chemical constituents of bed-sediment samples collected on the Mississippi River, February 22-23, 2010 .6

3. Consensus Based Probable Effect Concentration guidelines and associated bedsediment concentrations from samples collected on the Mississippi River. 


\section{Conversion Factors and Datums}

\begin{tabular}{lll}
\hline \multicolumn{1}{c}{ Multiply } & \multicolumn{1}{c}{ By } & \multicolumn{1}{c}{ To obtain } \\
\hline millimeter $(\mathrm{mm})$ & Length & \\
kilometer $(\mathrm{km})$ & 0.03937 & inch (in.) \\
& 0.6214 & mile (mi) \\
\hline gram $(\mathrm{g})$ & Mass & \\
kilogram $(\mathrm{kg})$ & 0.03527 & ounch, avoirdupois $(\mathrm{oz})$ \\
\hline
\end{tabular}

Temperature in degrees Celsius $\left({ }^{\circ} \mathrm{C}\right)$ may be converted to degrees Fahrenheit $\left({ }^{\circ} \mathrm{F}\right)$ as follows:

${ }^{\circ} \mathrm{F}=\left(1.8 x^{\circ} \mathrm{C}\right)+32$

Concentrations of chemical constituents in water are given in milligrams per liter $(\mathrm{mg} / \mathrm{L})$ or micrograms per liter $(\mu \mathrm{g} / \mathrm{L})$. 


\title{
Bed-Sediment Sampling and Analysis for Physical and Chemical Properties of the Lower Mississippi River near Memphis, Tennessee
}

\author{
By Robert A. Blanchard, Daniel M. Wagner, and Dennis A. Evans
}

\begin{abstract}
In February 2010, the U.S. Geological Survey, in cooperation with the U.S. Army Corps of Engineers, Memphis District, investigated the presence of inorganic elements and organic compounds in bed sediments of the lower Mississippi River. Selected sites were located in the navigation channel near river miles 737, 773, and 790 near Memphis, Tennessee. Bed-sediment samples were collected using a Shipek grab sampler mounted to a boom crane with a motorized winch. Samples then were processed and shipped to the U.S. Geological Survey Sediment Laboratory in Rolla, Missouri, the USGS National Water Quality Laboratory in Denver, Colorado, and to TestAmerica Laboratory, Inc. in West Sacramento, California. Samples were analyzed for grain size, inorganic elements (including mercury), and organic compounds. Chemical results were tabulated and listed with sediment-quality guidelines and presented with the physical property results. All of the bed material samples collected during this investigation yielded concentrations that were less than the ConsensusBased Probable Effect Concentration guidelines. The physical properties were tabulated and listed using a standard U.S. Geological Survey scale of sizes by class for sediment analysis. All of the samples collected during this investigation indicated a percent composition mostly comprised of sand, ranging from less than 0.125 millimeters to less than 2 millimeters.
\end{abstract}

\section{Introduction}

The U.S. Army Corps of Engineers (USACE) regularly dredges the navigation channel on the Mississippi River. Dredging performed by the USACE is covered by a nationwide permit; however, to ensure that each State's water-quality standards are followed, the USACE must obtain permits from individual States that are affected by dredging activities.

The Tennessee Department of Environment and Conservation (TDEC) is the chief environmental and natural resource regulatory agency in Tennessee. The U.S. Environmental
Protection Agency (USEPA) has delegated the responsibility of regulating seven main sources of waste, including the dredged bed sediment from the Mississippi River, to the TDEC. The TDEC is concerned that disturbance of bed sediment in the Mississippi River during dredging may cause chemical constituents attached to the bed sediment to be released into the waters of the Mississippi River. To determine the type and concentration of chemical constituents attached to the bed sediment, the U.S. Geological Survey (USGS) collected bed-sediment samples on the Mississippi River near Memphis, Tennessee.

In February 2010, the USGS, in cooperation with the USACE, Memphis District, investigated the presence of inorganic elements and organic compounds in bed sediments of the lower Mississippi River. A total of three samples were collected, one from each site, and analyzed for grain size, inorganic elements (including mercury) and organic compounds. Chemical results were tabulated and listed with sediment-quality guidelines and presented with the physical property results.

\section{Description of Study Area}

The study area is located within a 53-mile reach of the lower Mississippi River between river miles 737 (near Memphis, Tennessee) and 790 (near Osceola, Arkansas). Three sampling sites were located in the navigation channel near river miles 737, 773, and 790 (fig. 1). The sampling sites were assigned the following station numbers and names in the USGS National Water Information System (NWIS) database: 351002090034301 MISSISSIPPI RIVER RM 737, 353302089540002 MISSISSIPPI RIVER RM 773, and 354359089541903 MISSISSIPPI RIVER RM 790. These sites are hereinafter referred to as MISS-RM737, MISS-RM773, and MISS-RM790. Station numbers were derived from latitude and longitude coordinates at the respective sampling sites. 


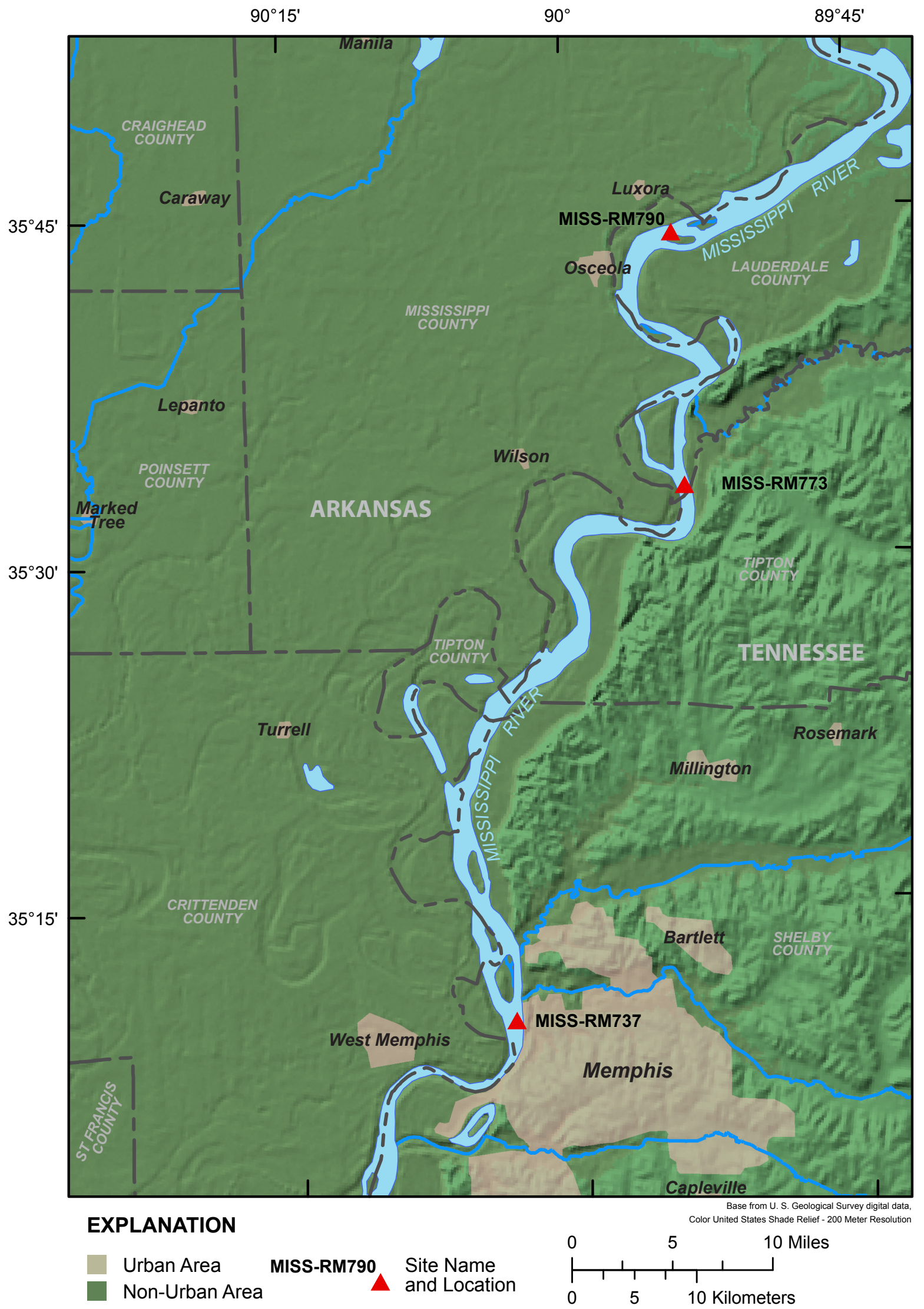

Figure 1. Location of study area. 


\section{Purpose and Scope}

The purpose of this report is to present the analytical results of the physical and chemical properties of bedsediment samples collected at MISS-RM737, MISS-RM773, and MISS-RM790. The physical properties were tabulated and listed with data collected in 1989 (Nordin and Queen, 1992) near the sampling locations for this study. Chemical properties were tabulated and listed with the sediment-quality guidelines set forth in the Consensus-Based Probable Effect Concentration (McDonald and others, 2000).

\section{Sample Collection and Preparation}

Bed-sediment samples were collected following methods described by Radtke (2005) using a Shipek grab sampler (fig. 2). The sampler was deployed with a boom and motorized winch and was lowered from a boat to the river bottom (fig. $3)$. Upon impact, the sampler automatically closes to capture the bed sediment (Radtke, 2005).

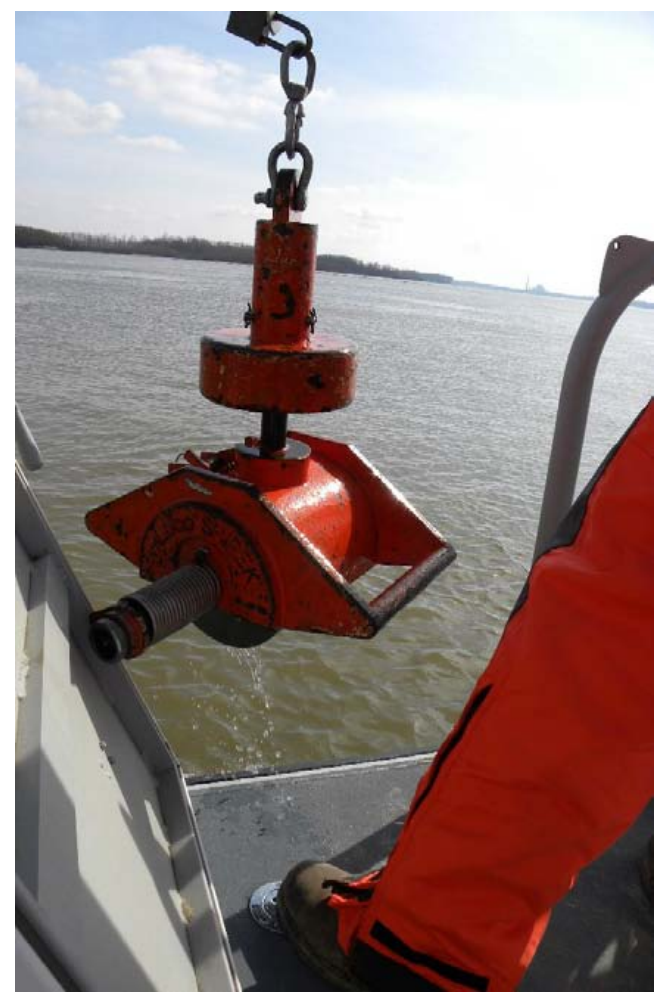

Figure 2. Shipek grab sampler (Photograph by Robert A. Blanchard, U.S. Geological Survey).

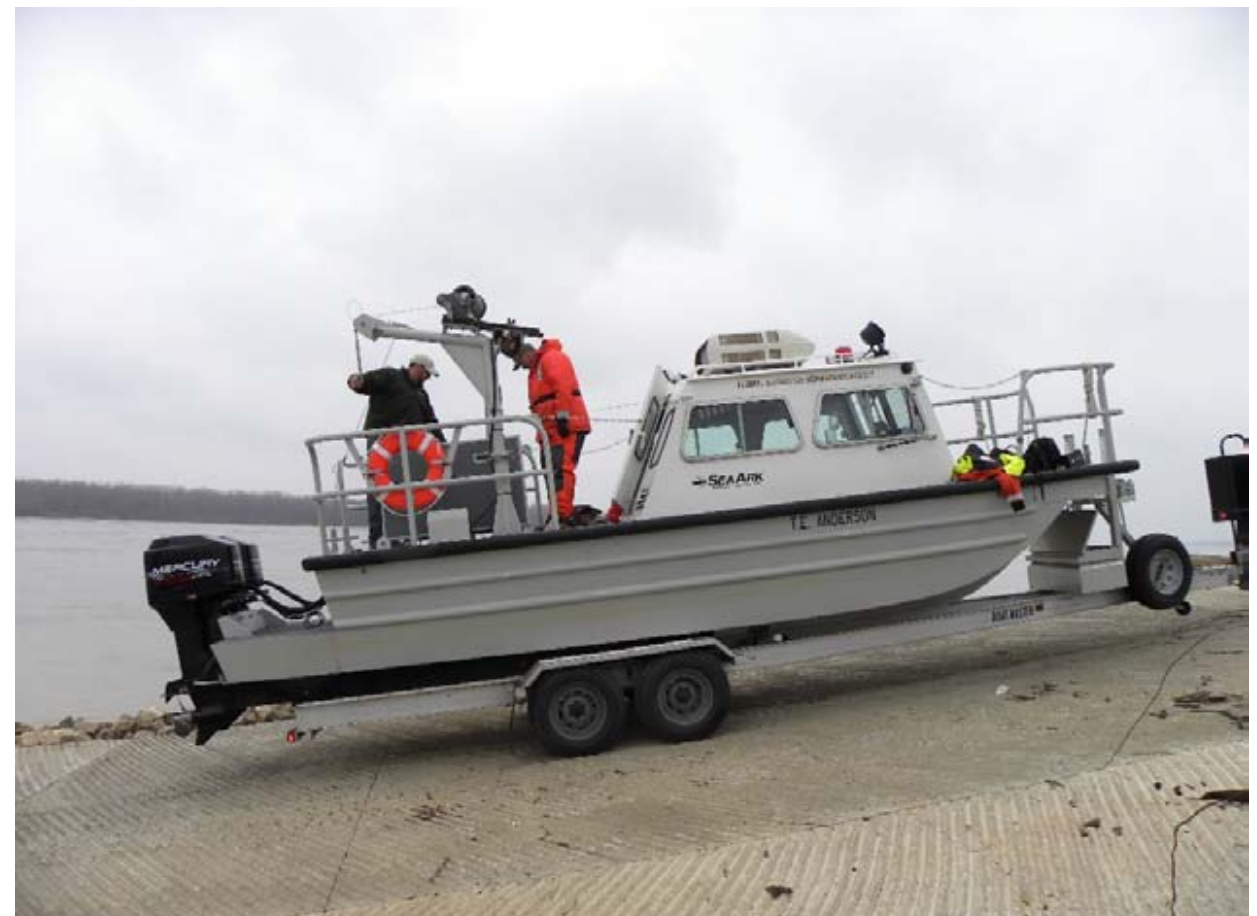

Figure 3. Boom and winch system mounted on the deck of the T.E. Anderson sampling boat (Photograph by Robert A. Blanchard, U.S. Geological Survey). 
At each site, one bed-sediment sample was collected, wet sieved (when necessary), subdivided into sample containers, and shipped to the appropriate analytical laboratory. Photographs of the sampling equipment used, methods and procedures for sample collection and the bed-sediment collected are included in appendix 1. Chain of custody procedures for samples submitted to USGS laboratories were followed according to protocol described by Murphy and others (1997). Chain of custody procedures for samples submitted to TestAmerica Laboratories, Inc., West Sacramento, California, was followed according to their protocol (TestAmerica, 2010). Copies of the chain of custody forms are included in appendix 2. Subsamples were analyzed for grain size at the USGS Sediment Laboratory, Rolla, Missouri; subsamples for inorganic elements (including mercury) and select organic compounds were analyzed at the USGS National Water Quality Laboratory, Denver, Colorado; subsamples for the organic compounds of dioxins and furans were analyzed by TestAmerica Laboratories, Inc. Inorganic samples were wet-sieved with a 2-millimeter ( $\mathrm{mm}$ ) nylon sieve. Mercury samples were prepared according to the methods described in Olson and DeWild (1999). Samples for organic compounds (including total carbon, pesticides, dioxins, and furans) were collected and prepared for analysis according to the methods described in Shelton and Capel (1994). Total carbon samples were processed according to the methods described in McGee and Demcheck (1995); samples were wet sieved using a 2-mm nylon sieve to remove detritus, debris and other larger particles prior to shipping.

\section{Bed-Sediment Analysis}

\section{Physical}

Grain size analysis was performed by the USGS Sediment Laboratory, Rolla, Missouri. Methods used for the determination of particle size are described by Guy (1969). Results for analysis of grain size from sites MISS-RM737, MISSRM773, and MISS-RM790 are shown in table 1 along with grain size distribution results from Nordin and Queen (1992). The Nordin and Queen (1992) samples were collected in close proximity to the 2010 sample sites and were dry sieved. Using a standard U.S. Geological Survey scale of sizes by class for sediment analysis, wherein $62.5 \mu \mathrm{m}$ to $2 \mathrm{~mm}$ is considered very fine to very coarse sand and $2 \mathrm{~mm}$ to $8 \mathrm{~mm}$ is considered very fine to fine gravel (Guy, 1969), the physical properties of the samples collected during this investigation indicated a percent composition mostly comprised of sand, ranging from less than $0.125 \mathrm{~mm}$ to less than $2 \mathrm{~mm}$ (table 1 ).

\section{Chemical}

Analysis for 41 inorganic elements (including mercury) and 134 organic compounds were performed at the USGS National Water Quality Laboratory (NWQL), Denver, Colorado. Analytical methods used by the NWQL for the analysis of inorganic elements are described by Skougstad and others (1979). Methods used for the analysis of organic compounds and total carbon and total organic carbon are described by Foreman and others (1995), Furlong and others (1996), and Arbogast (1990). Analysis for 25 dioxins and furans were performed by TestAmerica Laboratory, Inc., and followed the methods described by the U.S. Environmental Protection Agency (1994). Results of the chemical analyses and associated method reporting limits (MRL) and units for the 200 analytes are shown in table 2. The MRL is defined as the smallest measured concentration of a substance that can be reliably measured by using a given analytical method. It is the "less-than" value reported when an analyte is not detected or is detected at a concentration less than the MRL. The MRL for a particular analyte in a sample may be increased because of matrix interference during analysis while the reported MRL for that analyte may actually be lower in other samples that lack the matrix interference.

Sample analytes and the sediment-quality guidelines that are set forth in the Consensus Based Probable Effect Concentration or PEC (MacDonald and others, 2000) are listed in table 3 . The consensus-based guidelines were developed from published sediment-quality guidelines that have been derived from a variety of approaches. These guidelines consist of a probable effect concentration (PEC) above which adverse effects are expected to occur more often than not. The analytical results of this study indicated that all of the bed material samples yielded chemical concentrations that were less than the guidelines set forth in the Consensus-Based Probable Effect Concentration (table 3). 


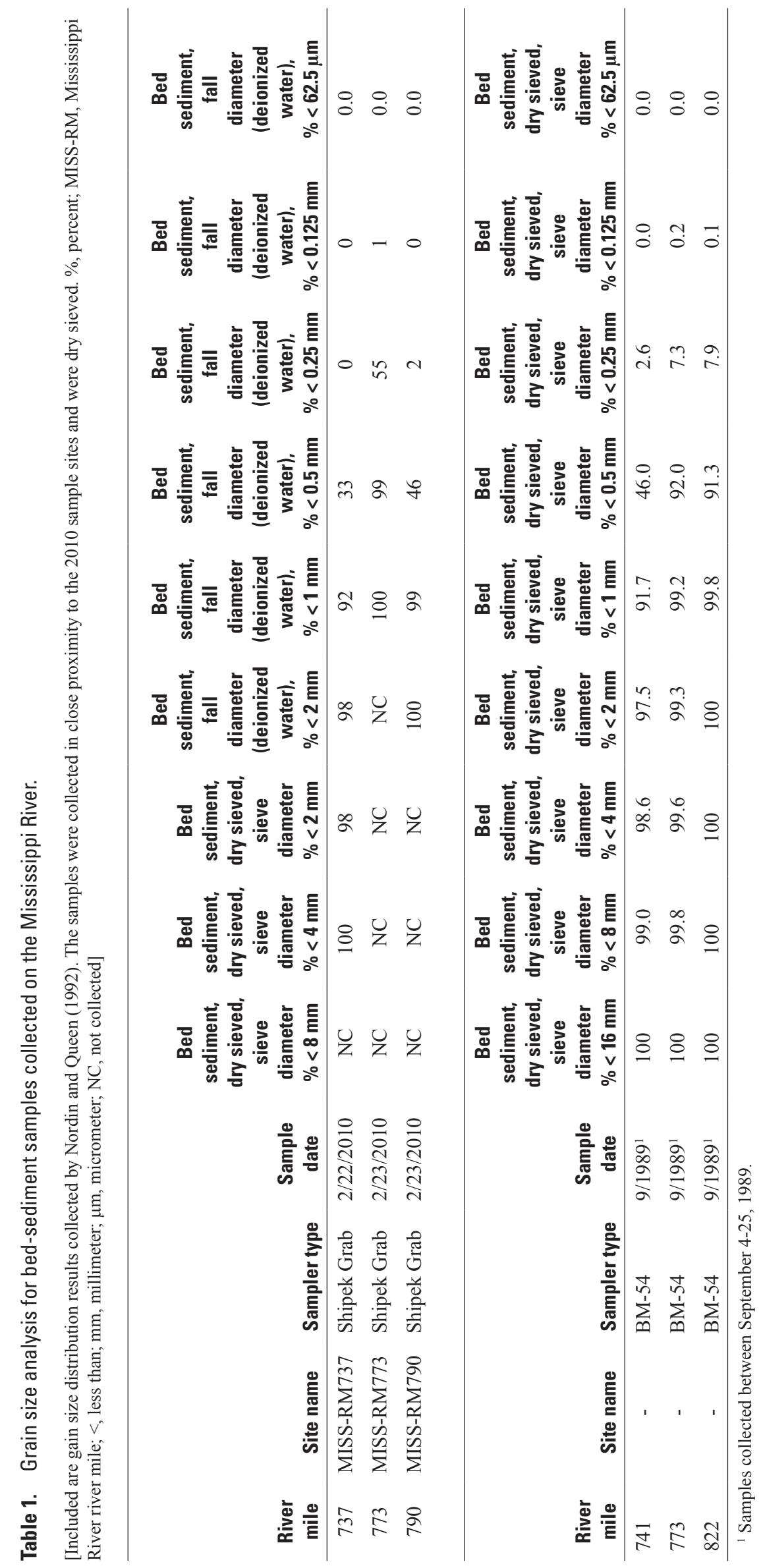


Table 2. Analytical results for chemical constituents of bed-sediment samples collected on the Mississippi River, February 22-23, 2010.

[MISS-RM, Mississippi River river mile; g/kg, grams per kilogram; $\mu \mathrm{g} / \mathrm{g}$, micrograms per gram; PAHs, polycyclic aromatic hydrocarbons; PCBs, polychlorinated biphenyls; $\mu \mathrm{g} / \mathrm{kg}$, micrograms per kilogram; pg/g, picograms per gram; pct, percent recovery; <, less than; NA, not applicable; ND, no detection]

\begin{tabular}{|c|c|c|c|c|c|}
\hline Chemical constituents & Units & $\begin{array}{c}\text { Method } \\
\text { reporting } \\
\text { limit }\end{array}$ & \multicolumn{3}{|c|}{ Site location } \\
\hline \multicolumn{6}{|l|}{ Inorganic elements } \\
\hline Aluminum & $\mu \mathrm{g} / \mathrm{g}$ & 25 & 1,410 & 1,560 & 1,510 \\
\hline Arsenic & $\mu \mathrm{g} / \mathrm{g}$ & 0.1 & 1.0 & 1.3 & 1.1 \\
\hline Barium & $\mu \mathrm{g} / \mathrm{g}$ & 0.2 & 13.4 & 15.5 & 13.4 \\
\hline Beryllium & $\mu \mathrm{g} / \mathrm{g}$ & 0.03 & 0.08 & 0.10 & 0.09 \\
\hline Bismuth & $\mu \mathrm{g} / \mathrm{g}$ & 0.2 & $<0.2$ & $<0.2$ & $<0.2$ \\
\hline Cerium & $\mu \mathrm{g} / \mathrm{g}$ & 0.1 & 11.0 & 20.5 & 13.3 \\
\hline Cesium & $\mu \mathrm{g} / \mathrm{g}$ & 0.003 & 0.10 & 0.15 & 0.11 \\
\hline Chromium & $\mu \mathrm{g} / \mathrm{g}$ & 0.1 & 2.93 & 4.20 & 3.58 \\
\hline Cobalt & $\mu \mathrm{g} / \mathrm{g}$ & 0.1 & 3.13 & 2.03 & 2.29 \\
\hline Copper & $\mu \mathrm{g} / \mathrm{g}$ & 0.1 & 1.19 & 0.96 & 0.99 \\
\hline Gallium & $\mu \mathrm{g} / \mathrm{g}$ & 0.02 & 0.80 & 1.00 & 0.84 \\
\hline Iron & $\mu \mathrm{g} / \mathrm{g}$ & 2.1 & 3,330 & 4,590 & 3,370 \\
\hline Lanthanum & $\mu \mathrm{g} / \mathrm{g}$ & 0.05 & 5.73 & 9.50 & 6.78 \\
\hline Molybdenum & $\mu \mathrm{g} / \mathrm{g}$ & 0.001 & 0.04 & 0.07 & 0.04 \\
\hline Nickel & $\mu \mathrm{g} / \mathrm{g}$ & 0.001 & 7.8 & 5.0 & 6.1 \\
\hline Niobium & $\mu \mathrm{g} / \mathrm{g}$ & 0.2 & $<0.2$ & $<0.2$ & $<0.2$ \\
\hline Phosphorus & $\mu \mathrm{g} / \mathrm{g}$ & 5.0 & 80 & 200 & 100 \\
\hline Potassium & $\mu \mathrm{g} / \mathrm{g}$ & 20 & 200 & 200 & 200 \\
\hline Rubidium & $\mu \mathrm{g} / \mathrm{g}$ & 0.01 & 1.37 & 1.75 & 1.56 \\
\hline Scandium & $\mu \mathrm{g} / \mathrm{g}$ & 0.6 & $<0.6$ & 0.7 & $<0.6$ \\
\hline Selenium & $\mu \mathrm{g} / \mathrm{g}$ & 0.1 & $<0.1$ & $<0.1$ & $<0.1$ \\
\hline Silver & $\mu \mathrm{g} / \mathrm{g}$ & 3.0 & $<3.0$ & $<3.0$ & $<3.0$ \\
\hline Sodium & $\mu \mathrm{g} / \mathrm{g}$ & 500 & $<500$ & $<500$ & $<500$ \\
\hline Strontium & $\mu \mathrm{g} / \mathrm{g}$ & 0.80 & 5.96 & 12.60 & 7.80 \\
\hline Sulfate & $\mu \mathrm{g} / \mathrm{g}$ & 2.0 & $<2.0$ & $<2.0$ & $<2.0$ \\
\hline
\end{tabular}


Table 2. Analytical results for chemical constituents of bed-sediment samples collected on the Mississippi River, February 22-23, 2010.-Continued

[MISS-RM, Mississippi River river mile; g/kg, grams per kilogram; $\mu \mathrm{g} / \mathrm{g}$, micrograms per gram; PAHs, polycyclic aromatic hydrocarbons; PCBs, polychlorinated biphenyls; $\mu \mathrm{g} / \mathrm{kg}$, micrograms per kilogram; pg/g, picograms per gram; pct, percent recovery; <, less than; NA, not applicable; ND, no detection]

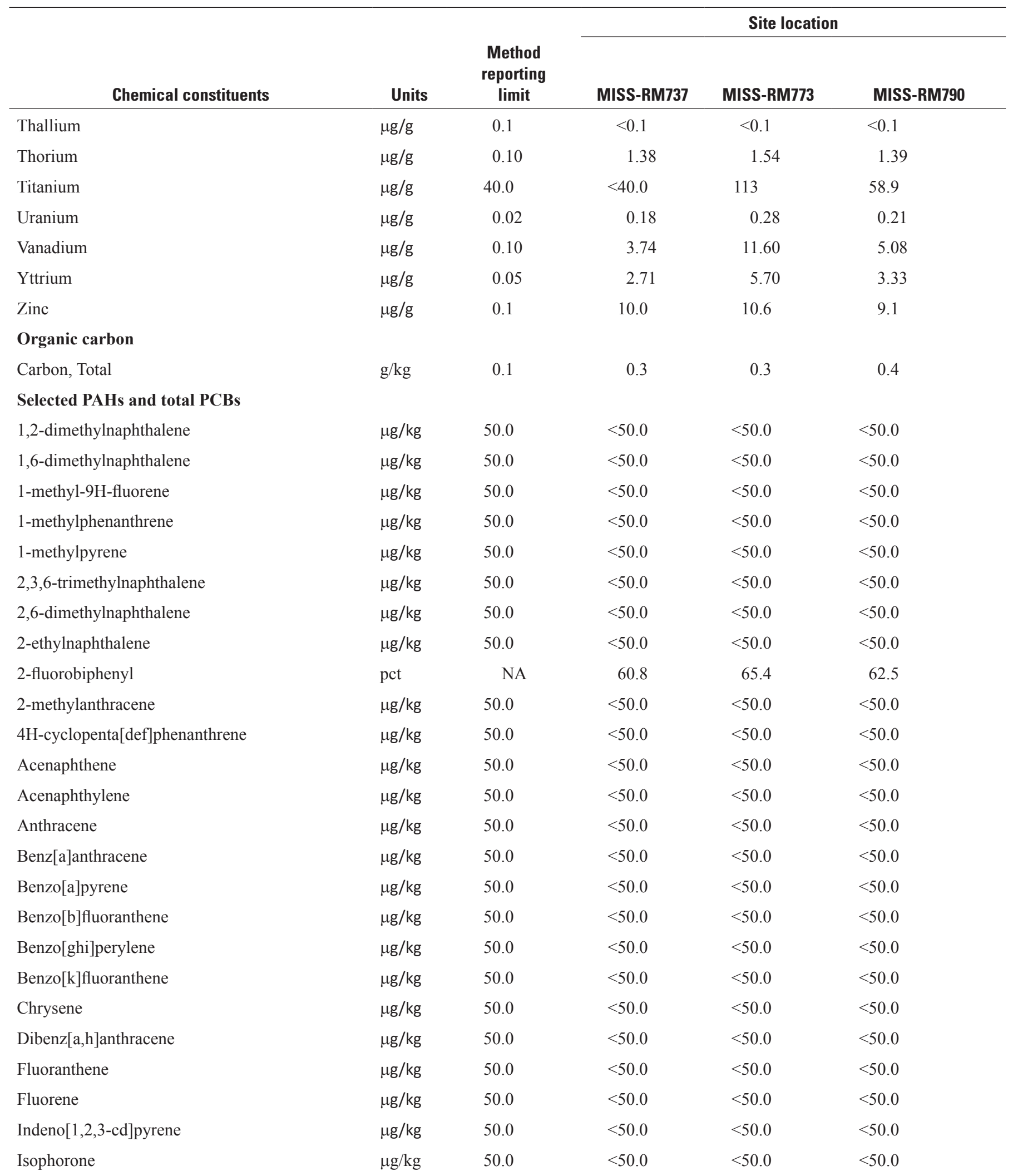


Table 2. Analytical results for chemical constituents of bed-sediment samples collected on the Mississippi River, February 22-23, 2010.-Continued

[MISS-RM, Mississippi River river mile; g/kg, grams per kilogram; $\mu \mathrm{g} / \mathrm{g}$, micrograms per gram; PAHs, polycyclic aromatic hydrocarbons; PCBs, polychlorinated biphenyls; $\mu \mathrm{g} / \mathrm{kg}$, micrograms per kilogram; pg/g, picograms per gram; pct, percent recovery; <, less than; NA, not applicable; ND, no detection]

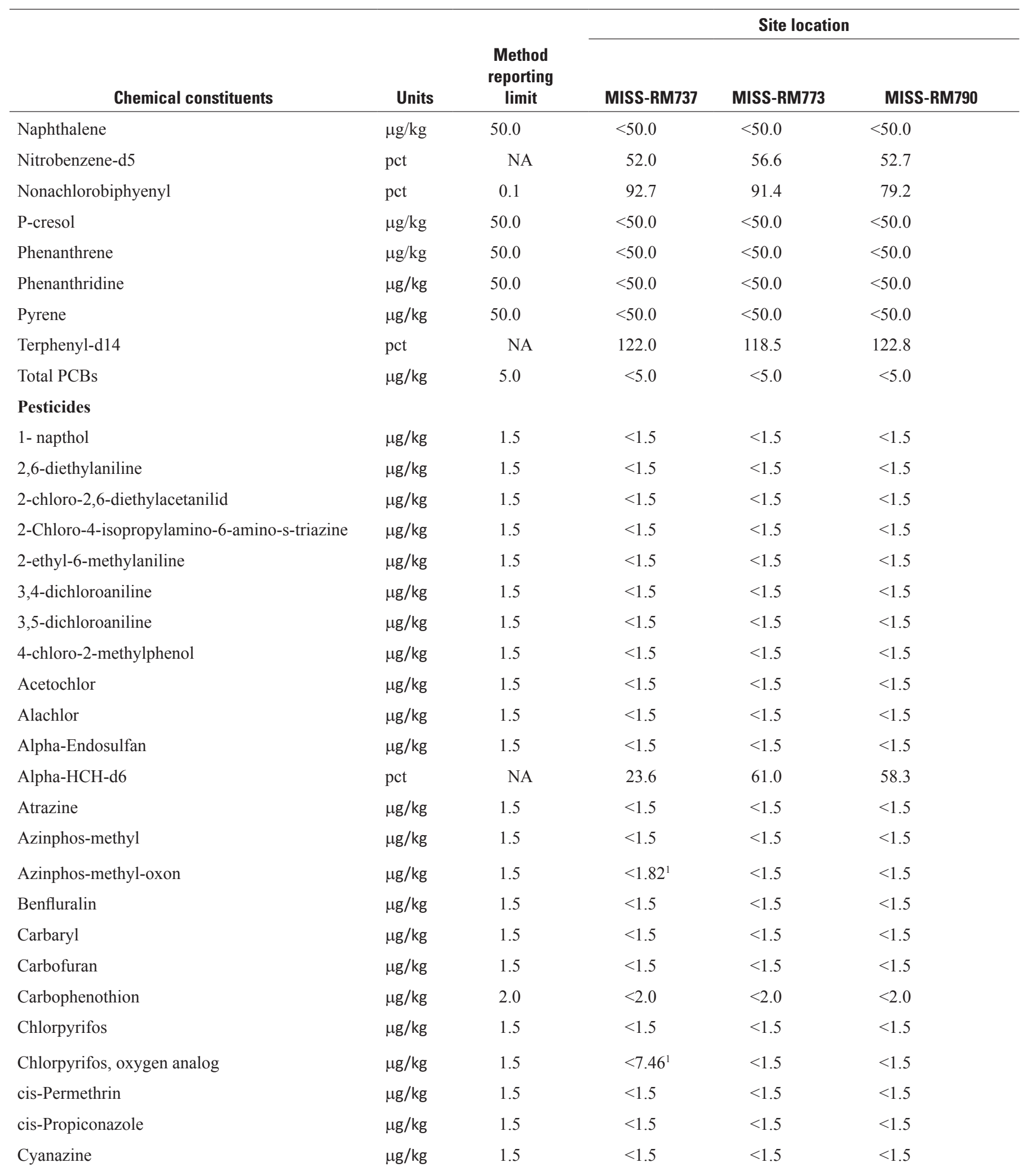


Table 2. Analytical results for chemical constituents of bed-sediment samples collected on the Mississippi River, February 22-23, 2010.-Continued

[MISS-RM, Mississippi River river mile; g/kg, grams per kilogram; $\mu \mathrm{g} / \mathrm{g}$, micrograms per gram; PAHs, polycyclic aromatic hydrocarbons; PCBs, polychlorinated biphenyls; $\mu \mathrm{g} / \mathrm{kg}$, micrograms per kilogram; pg/g, picograms per gram; pct, percent recovery; <, less than; NA, not applicable; ND, no detection]

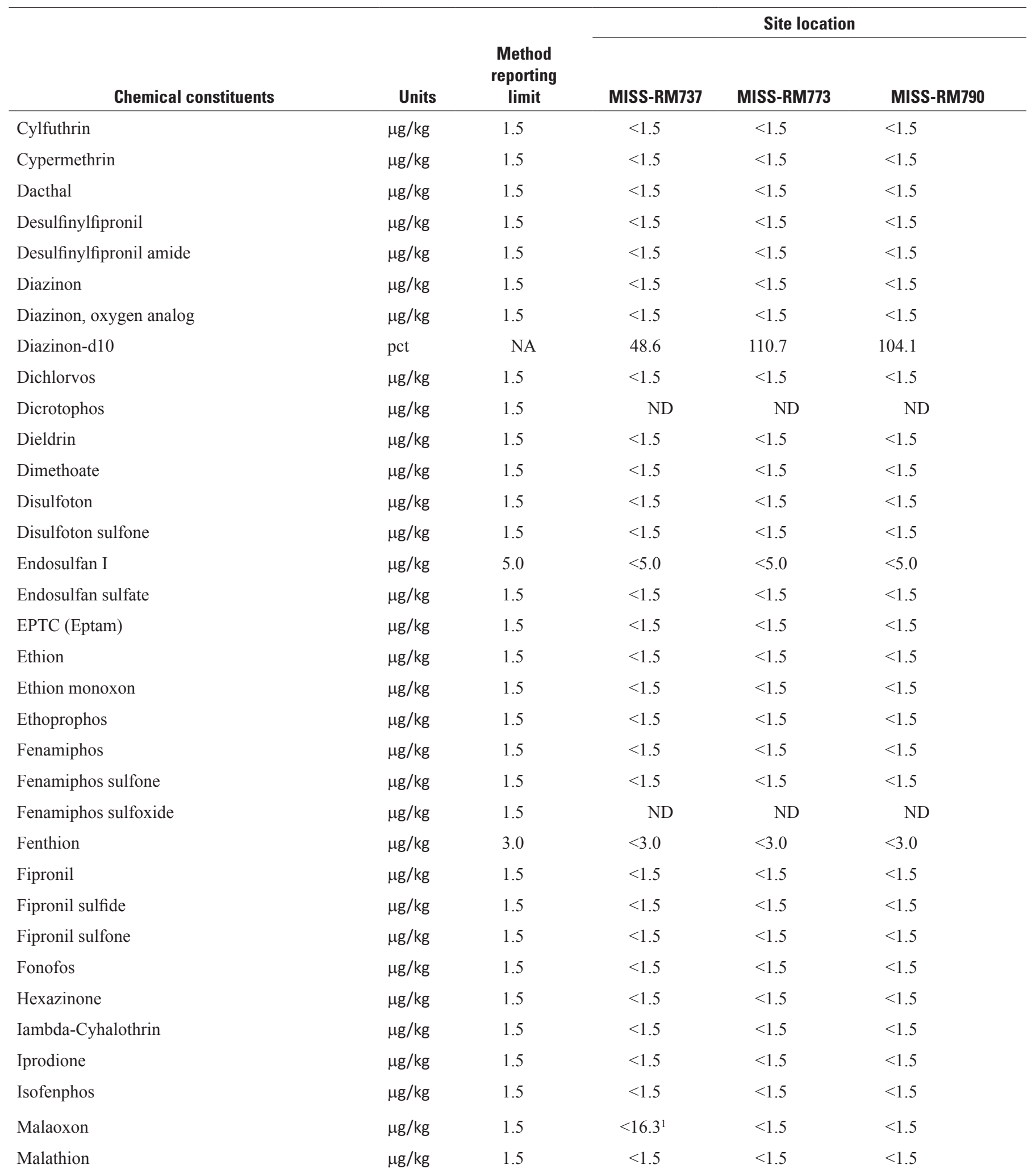


Table 2. Analytical results for chemical constituents of bed-sediment samples collected on the Mississippi River, February 22-23, 2010.-Continued

[MISS-RM, Mississippi River river mile; g/kg, grams per kilogram; $\mu \mathrm{g} / \mathrm{g}$, micrograms per gram; PAHs, polycyclic aromatic hydrocarbons; PCBs, polychlorinated biphenyls; $\mu \mathrm{g} / \mathrm{kg}$, micrograms per kilogram; pg/g, picograms per gram; pet, percent recovery; <, less than; NA, not applicable; ND, no detection]

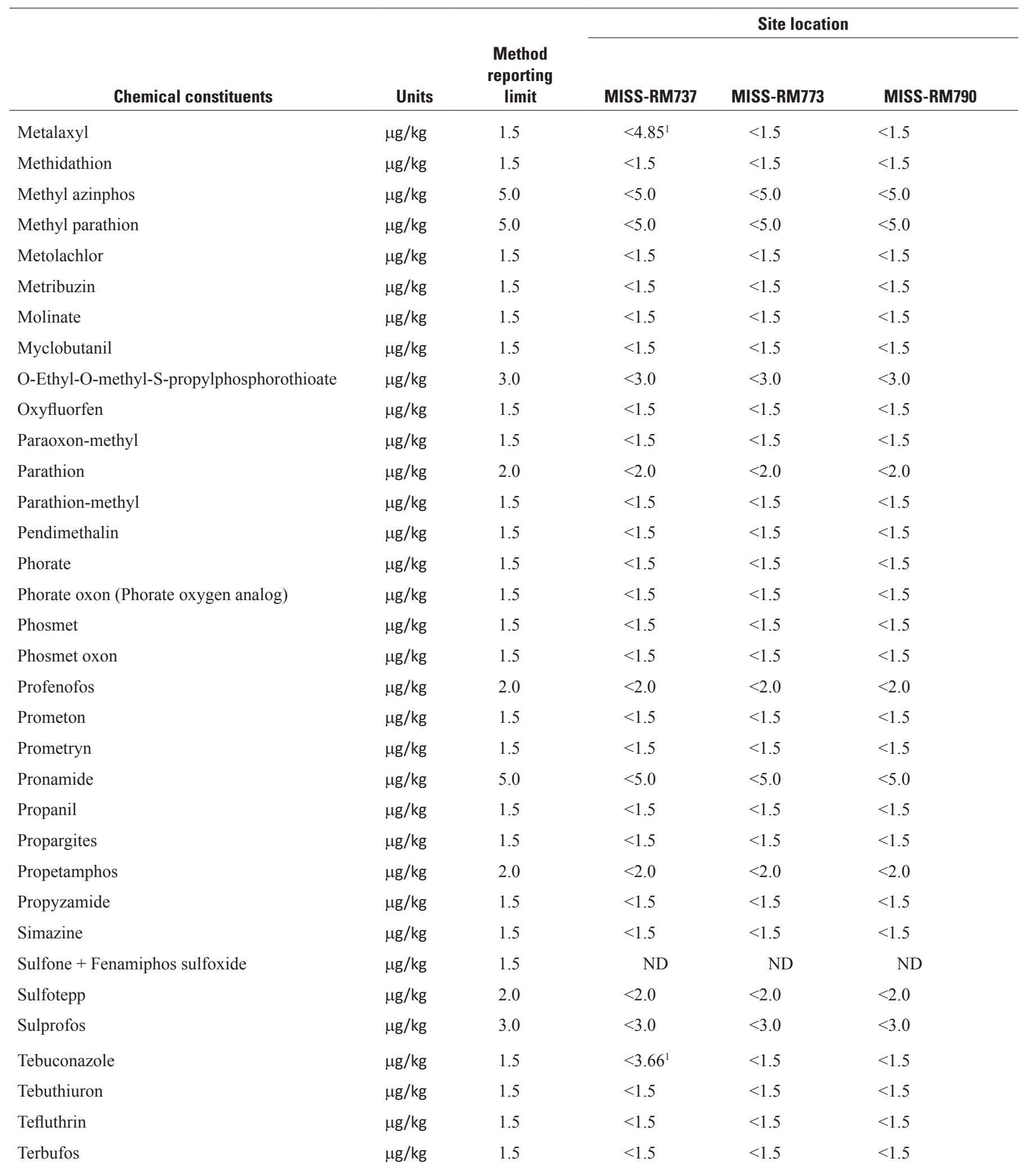


Table 2. Analytical results for chemical constituents of bed-sediment samples collected on the Mississippi River, February 22-23, 2010.-Continued

[MISS-RM, Mississippi River river mile; g/kg, grams per kilogram; $\mu \mathrm{g} / \mathrm{g}$, micrograms per gram; PAHs, polycyclic aromatic hydrocarbons; PCBs, polychlorinated biphenyls; $\mu \mathrm{g} / \mathrm{kg}$, micrograms per kilogram; pg/g, picograms per gram; pct, percent recovery; <, less than; NA, not applicable; ND, no detection]

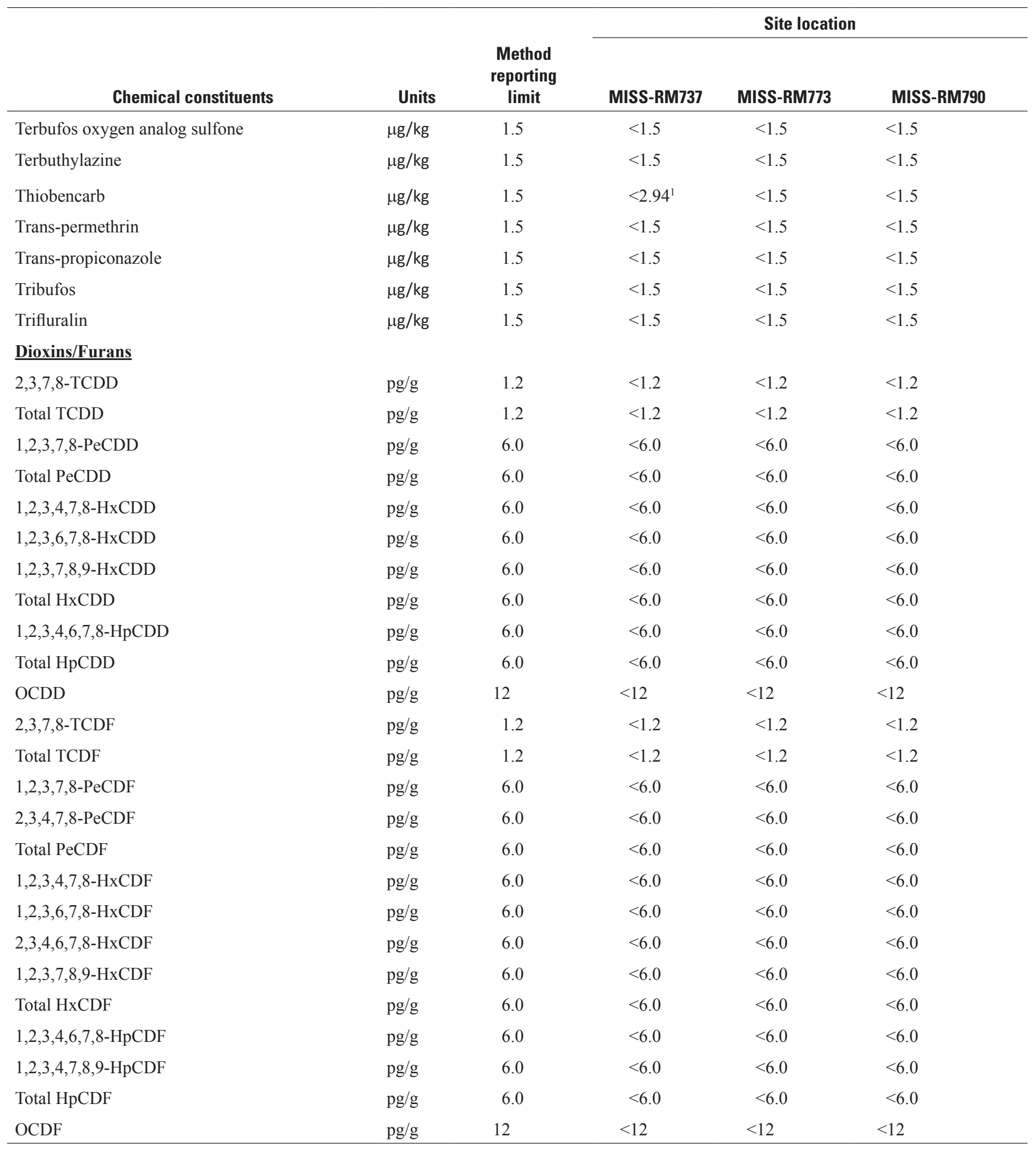




\section{Bed-Sediment Sampling and Analysis for Physical and Chemical Properties of the Lower Mississippi River}

Table 3. Consensus Based Probable Effect Concentration (PEC) guidelines (MacDonald and others, 2000) and associated bedsediment concentrations from samples collected on the Mississippi River.

$[\mathrm{mg} / \mathrm{kg}$ DW, milligrams per kilogram dry weight; $\mu \mathrm{g} / \mathrm{kg}$ DW, micrograms per kilogram dry weight; MISS-RM, Mississippi River river mile; <, less than]

Site location

Checmial constituents

\begin{tabular}{|c|}
\hline $\begin{array}{l}\text { Consensus- } \\
\text { based PEC } \\
\text { (mg/kg DW) }\end{array}$ \\
\hline
\end{tabular}

MISS-RM737

MISS-RM773

MISS-RM790

Trace element (concentrations in $\mathrm{mg} / \mathrm{kg} \mathrm{DW}$ )

Arsenic

Cadmium

Chromium

Copper

Lead

Mercury

Nickel

Zinc

Polycyclic aromatic hydrocarbons (PAH) (concentrations in $\mu \mathrm{g} / \mathrm{kg} \mathrm{DW}$ )

Anthracene

Fluorene

Naphthalene

Phenanthrene

Benz[a]anthracene

Benzo(a)pyrene

Chrysene

Fluoranthene

Pyrene

Total PAHs
-- 845

-- 536

-- $\quad 561$

$--\quad 1,170$

-- 1,050

-- 1,450

-- 1,290

-- 2,230

-- $\quad 1,520$

-- $\quad 22,800$
$-$

$-$

$-$

$--$

$--$

$--$

$--$

$--$

(1)

1.0

1.3

1.1

0.02

0.02

0.02

2.93

4.2

3.58

1.19

0.96

0.99

1.7

2.5

1.9

$<0.0072$

$<0.0072$

$<0.0072$

7.8

5.0

6.1

10.0

10.6

9.1

Polychlorinated biphenyls (PCB) (concentrations in $\mu \mathrm{g} / \mathrm{kg} \mathrm{DW}$ )

Total PCBs

-- 676

$<50.0$
$<50.0$
$<50.0$
$<50.0$
$<50.0$
$<50.0$
$<50.0$
$<50.0$
$<50.0$
$<450$

$<50.0$

$<50.0$

$<50.0$

$<50.0$

$<50.0$

$<50.0$

$<50.0$

$<50.0$

Organochlorine pesticides (concentrations in $\mu \mathrm{g} / \mathrm{kg} \mathrm{DW}$ )

Chlordane

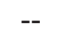

Dieldrin

17.6

$--\quad 61.8$

Sum DDD

$\begin{array}{ll}-- & 28.0\end{array}$

Sum DDE

$--\quad 31.3$

Sum DDT

$\begin{array}{ll}-- & 62.9\end{array}$

Total DDTs

Endrin

$\begin{array}{ll}-- & 572\end{array}$

Heptachlor Epoxide

-- 207

$<5.0$

$<5.0$

$<5.0$

Lindane (gamma-BHC)

$\begin{array}{ll}-- & 16.0\end{array}$

$<1.5 \quad<1.5$

$<1.5$

$<1.5$

$<1.5$

$<1.5$

$<2.5$

$<2.5$

$<2.5$

$<1.5$

$<1.5$

$<1.0$

$<1.5$

$<1.0$

$<5.0$

$<1.0$

$<5.0$

$<1.0$

$<5.0$

$<1.0$

$<1.5$

$<1.0$

$<1.5$

$--$

4.99

$<0.5$

$<1.5$

$<0.5$ 


\section{Summary}

In February 2010, the U.S. Geological Survey, in cooperation with the U.S. Army Corps of Engineers, Memphis District, investigated the presence of inorganic elements and organic compounds in bed-sediment samples of the lower Mississippi River. Selected sites were located in the navigation channel near river miles 737, 773 and 790 near Memphis, Tennessee. Bed-sediment samples were collected using a Shipek grab sampler mounted to a boom crane with a motorized winch. Samples then were processed and shipped to the U.S. Geological Survey Sediment Laboratory in Rolla, Missouri, the USGS National Water Quality Laboratory in Denver, Colorado, and to TestAmerica Laboratory, Inc. in West Sacramento, California. Three samples were collected, one from each site, and analyzed for grain size, inorganic elements (including mercury) and organic compounds. Chemical results for the 200 analytes measured were tabulated and listed with sediment-quality guidelines and presented with the physical property results. All of the bed -sediment samples collected during this investigation yielded chemical concentrations that were less than the Consensus-Based Probable Effect Concentration guidelines (MacDonald and others, 2000). The physical properties were tabulated and listed using a standard U.S. Geological Survey scale of sizes by class for sediment analysis. All three of the bed-sediment samples collected during this investigation indicated a percent composition mostly comprised of sand, ranging from less than $0.125 \mathrm{~mm}$ to less than $2 \mathrm{~mm}$. 


\section{References Cited}

Arbogast, B.F., 1990, Quality assurance manual for the Branch of Geochemistry, U.S. Geological Survey Open-File Report 90-668, $184 \mathrm{p}$.

Foreman, W.T., Connor, B.F., Furlong, E.T., Vaught, D.G., and Merten, L.M., 1995, Methods of analysis by the U.S. Geological Survey National Water Quality Laboratory---Determination of organochlorine pesticides and polychlorinated biphenyls in bottom sediment by dual capillary-column gas chromatography with electron-capture detection: U.S. Geological Survey Open-File Report 95-140, 78 p.

Furlong, E.T., Vaught, D.G., Merten, L.M., Foreman, W.T., and Gates, P.M., 1996, Methods of analysis by the U.S. Geological Survey National Water Quality Laboratory--Determination of semivolatile organic compounds in bottom sediment by solvent extraction, gel permeation chromatographic fractionation, and capillary-column gas chromatography/mass spectrometry: U.S. Geological Survey OpenFile Report 95-719, 67 p.

Guy, H.P., 1969, Laboratory theory and methods for sediment analysis: U.S. Geological Survey Techniques of WaterResources Investigations, book 5, chap. C1, 58 p.

MacDonald, D.D., Ingersoll, C.G, and Berger, T.A., 2000, Development and evaluation of consensus-based sediment quality guidelines for freshwater ecosystems: Archives of Environmental Contamination and Toxicology, v. 39, p. 20-31.

McGee, B.D., and Demcheck, D.K., 1995, Occurrence and estimation of trace elements in bottom material for selected streams in coastal Louisiana, 1991-92: Louisiana Department of Transportation and Development Water Resources Technical Report no. 57, 49 p.

Murphy, C., Briggs, P., Adrain, B., Wilson, S., Hageman, P., and Theodorakos, P., 1997, Chain of custody----Recommendations for acceptance and analysis of evidentiary geochemical samples: U.S. Geological Survey Circular 1138, 26 p.

Nordin, C.F., and Queen, B.S., 1992, Particle size distributions of bed sediments along the thalweg of the Mississippi River, Cairo, Illinois, to Head of Passes, September 1989, Appendix A, Tables 1, 3, and 4, U.S. Army Corps of Engineer Waterways Experiment Sta., Vicksburg, MS, Potamology Progr. (P-1) Rept. 7, 93 p.

Olson, M.L., and DeWild, J.F., 1999, Low-level collection techniques and species-specific analytical methods for mercury in water, sediment, and biota: U.S. Geological Survey Water-Resources Investigations Report 99-4018b, 11 p.
Radtke, D.B., Revised 2005, Bottom-material samples: U.S. Geological Survey Techniques of Water Resources Investigations, book 9, chap. A8, accessed February 15, 2010 at http://pubs.water.usgs.gov/twri9A8/

Shelton, L.R., and Capel, P.D., 1994, Guidelines for collecting and processing samples of stream bed sediment for analysis of trace elements and organic contaminants for the National Water-Quality Assessment Program: U.S. Geological Survey Open-File Report 94-458, 20 p.

Skougstad, M.W., Fishman, M.J., Friedman, L.C., Erdmann, D.E., and Duncan, S.S., 1979, Methods for determination of inorganic substances in water and fluvial sediments: U.S. Geological Survey Techniques of Water-Resources Investigations, book 5, chap. A1, $626 \mathrm{p}$.

TestAmerica, Inc., 2010, TestAmerica Terms and Conditions of Sale (Short Form), 1p. accessed May 26, 2010, at http:// www.testamericainc.com/downloads/TA_ShortFormTs\&Cs. pdf

U.S. Environmental Protection Agency, 1994, Method 8290: polychlorinated dibenzodioxins (PCDDs) and polychlorinated dibenzofurans (PCDFs) by high-resolution gas chromatography/high-resolution mass spectrometry (HRGC/ HRMS). Revision O. In: Test methods for evaluating solid waste, physical/chemical methods. EPA Doc. SW-846; 71 p. 
Appendixes 1-2 


\section{Appendix 1. Photographs showing sampling equipment, sampling methods and procedures, and bed-sediment samples.}

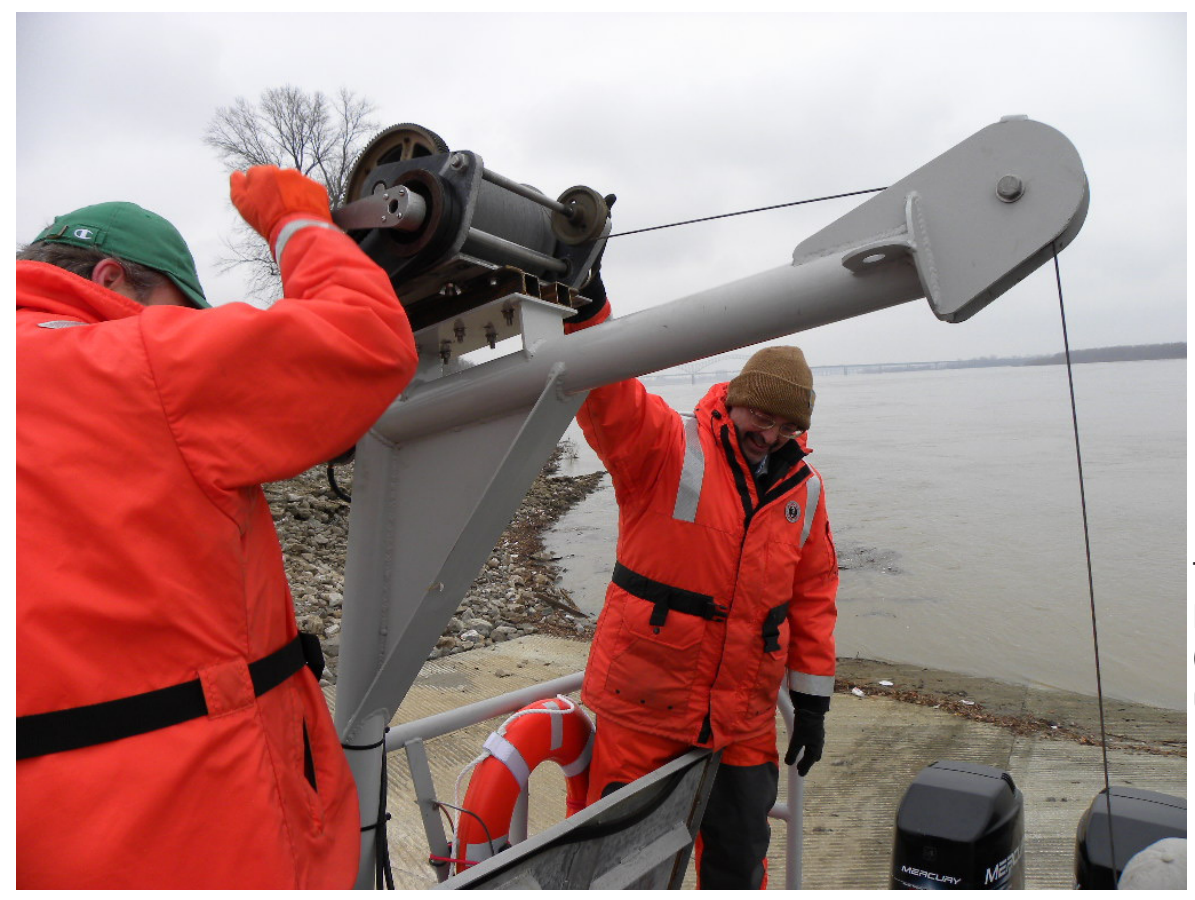

Testing the boom and winch system before departure on the Mississippi River (Photograph by Daniel M. Wagner, U.S. Geological Survey).

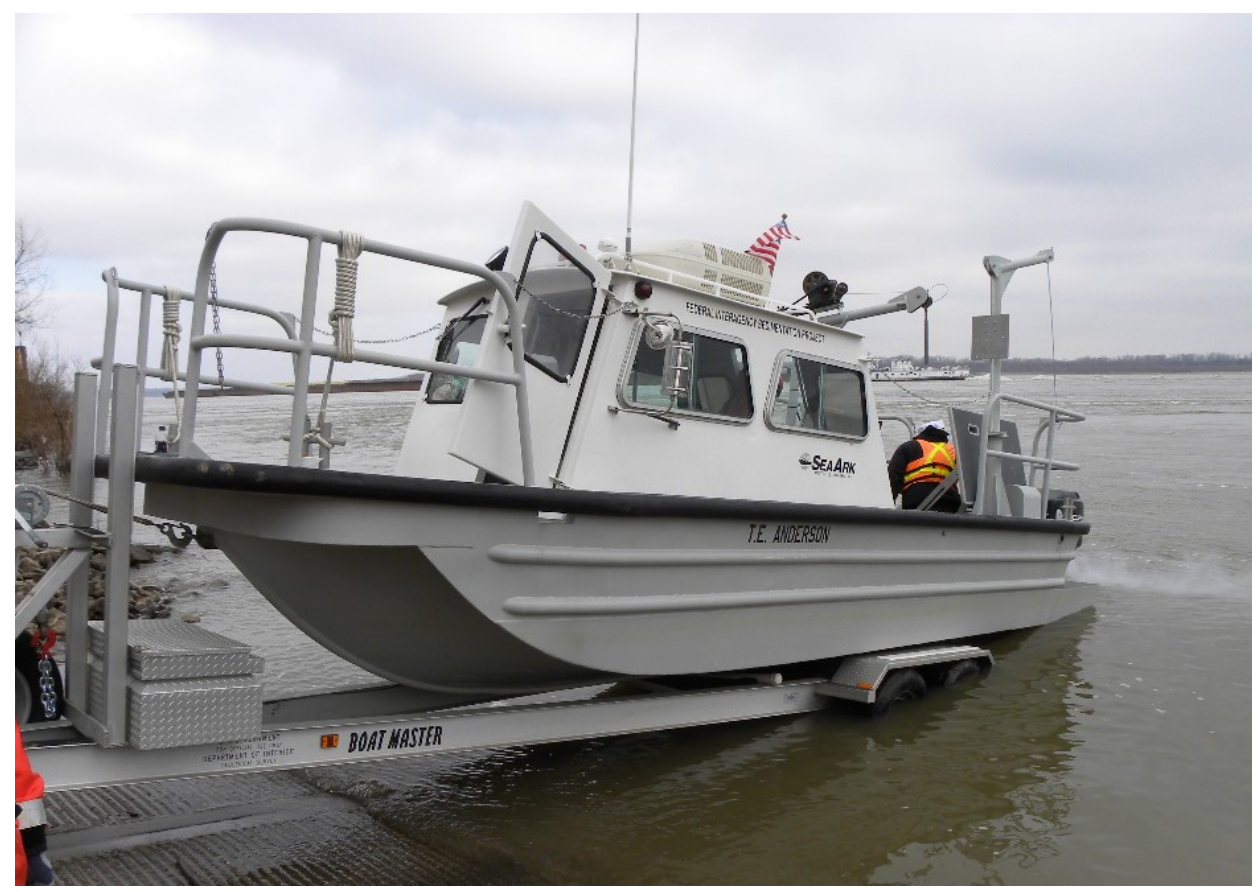

The T.E. Anderson sampling boat used for collection of bed sediment on the Mississippi River (Photograph by Robert A. Blanchard, U.S. Geological Survey). 


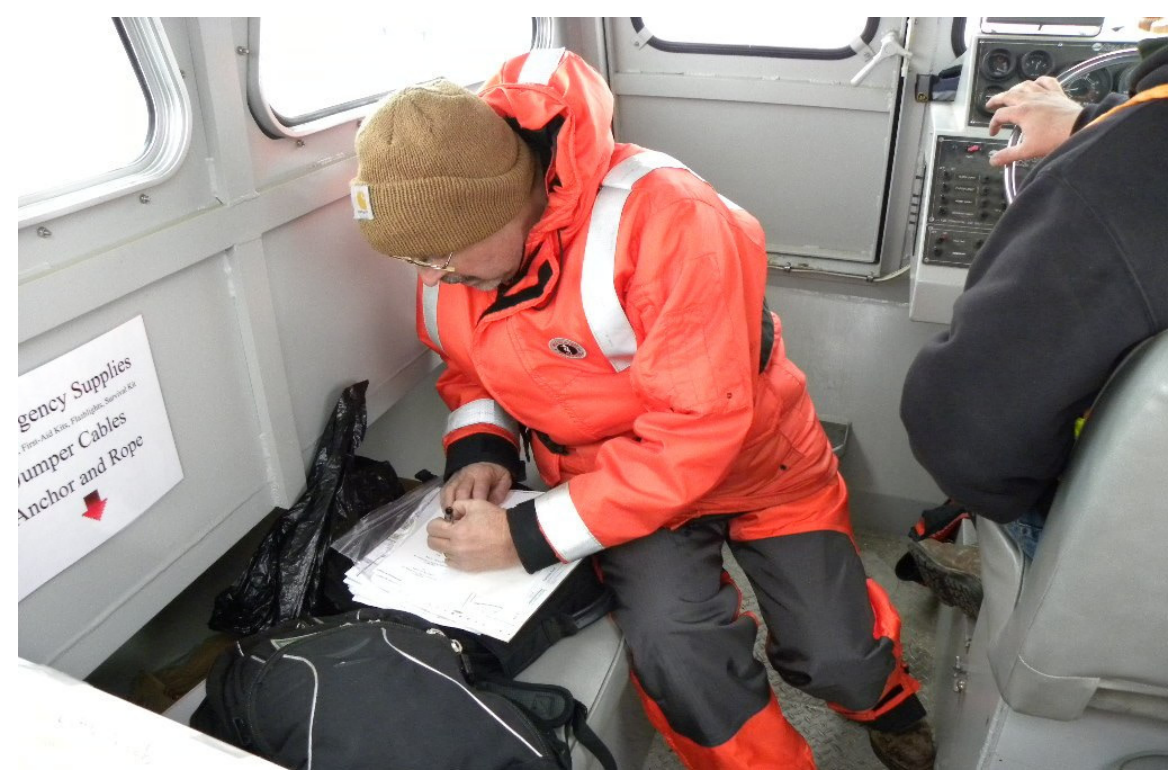

Preparing chain of custody forms for sample collection (Photograph by Robert A. Blanchard, U.S. Geological Survey).

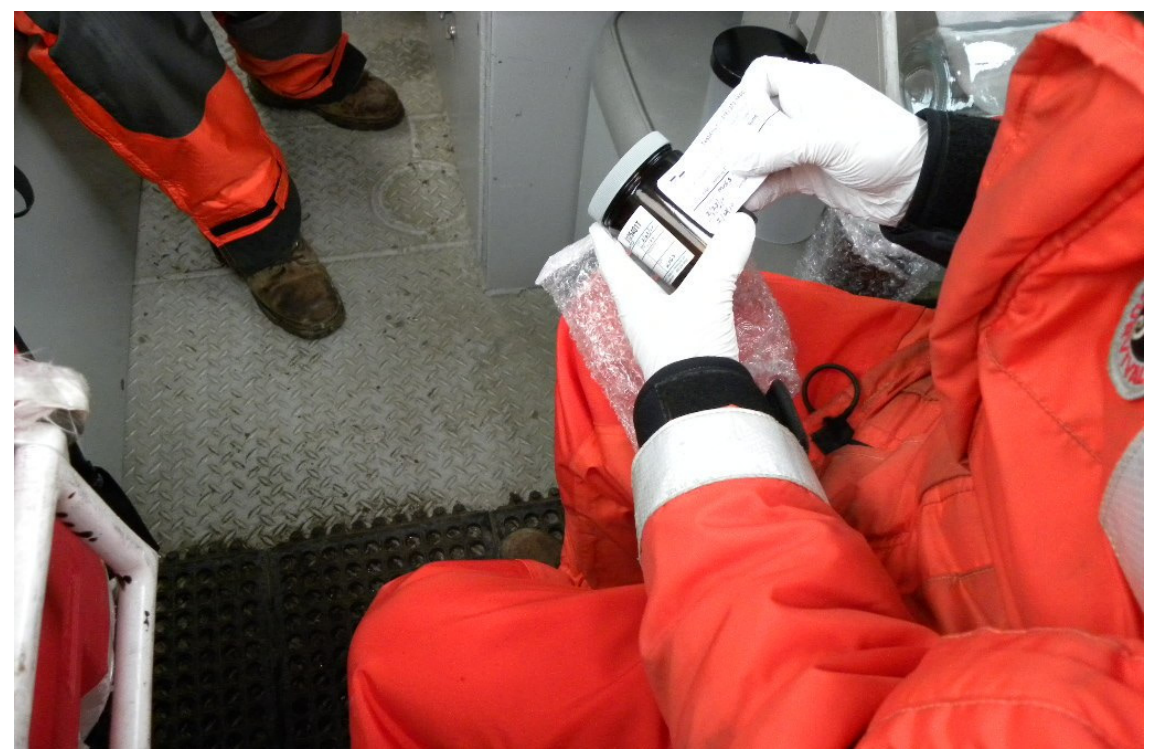

Preparing labels for sample bottles (Photograph by Robert A. Blanchard, U.S. Geological Survey).

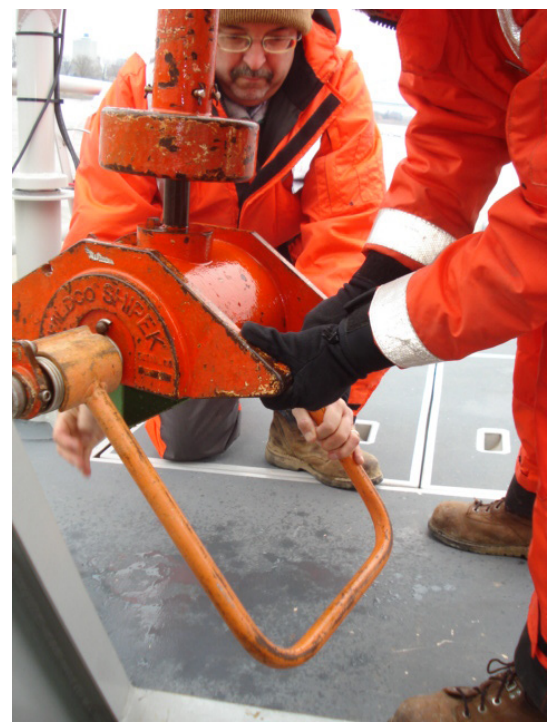

Preparing the Shipek grab

sampler for collection of bed sediment (Photograph by Robert A. Blanchard, U.S. Geological Survey).

Deployment of the Shipek grab sampler for collection of bed sediment (Photograph by Robert A. Blanchard, U.S. Geological Survey).

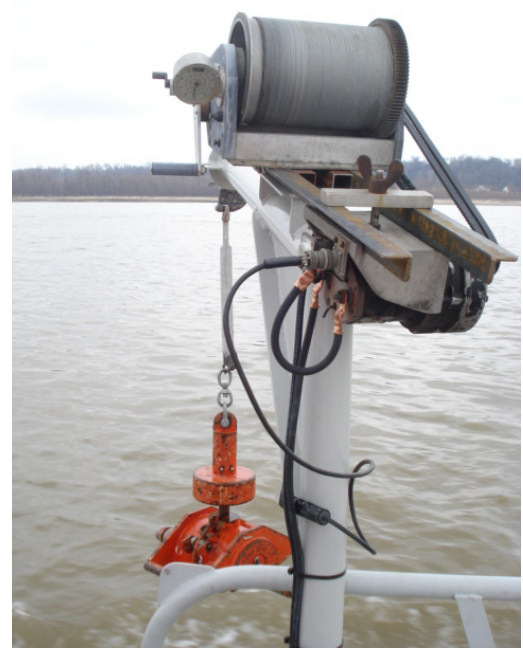




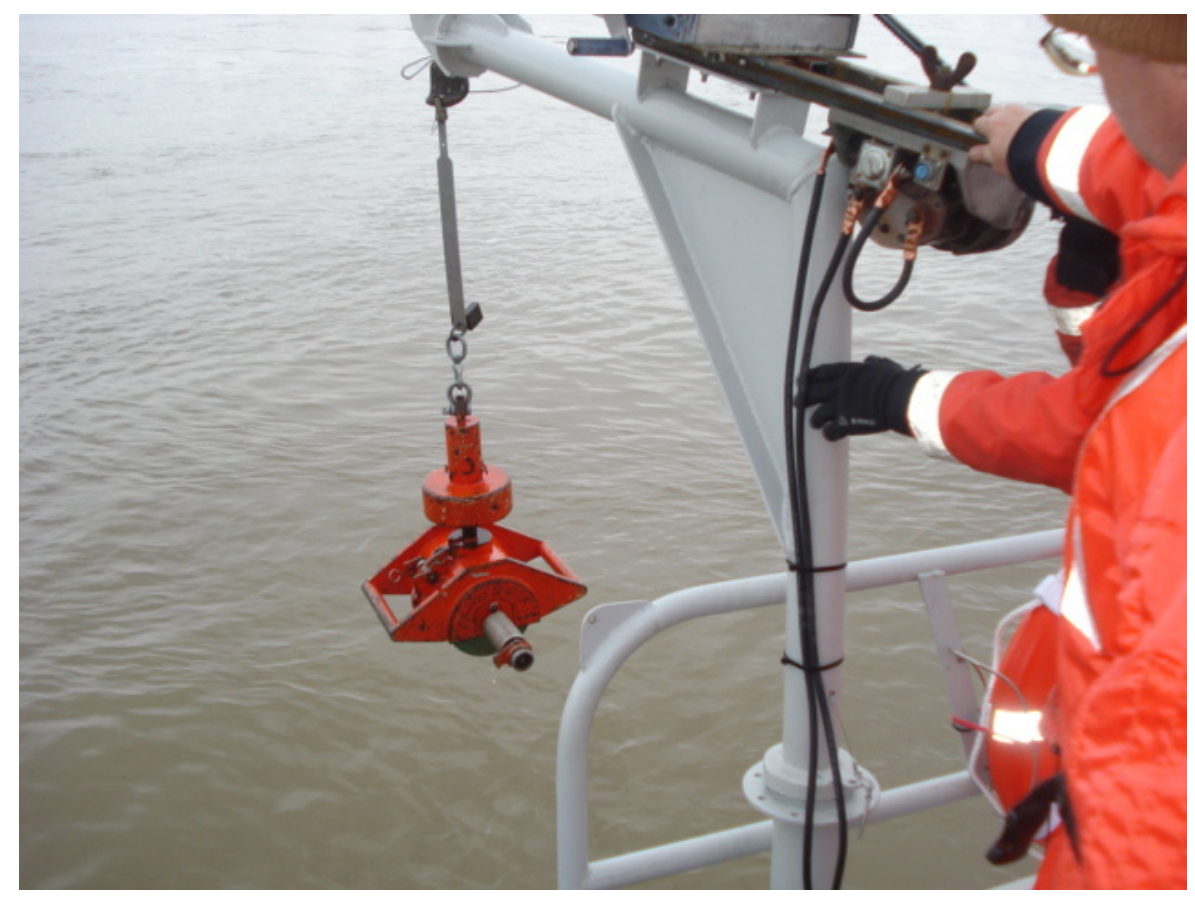

Retrieval of the Shipek grab sampler with bed-sediment sample (Photograph by Robert A. Blanchard, U.S. Geological Survey).

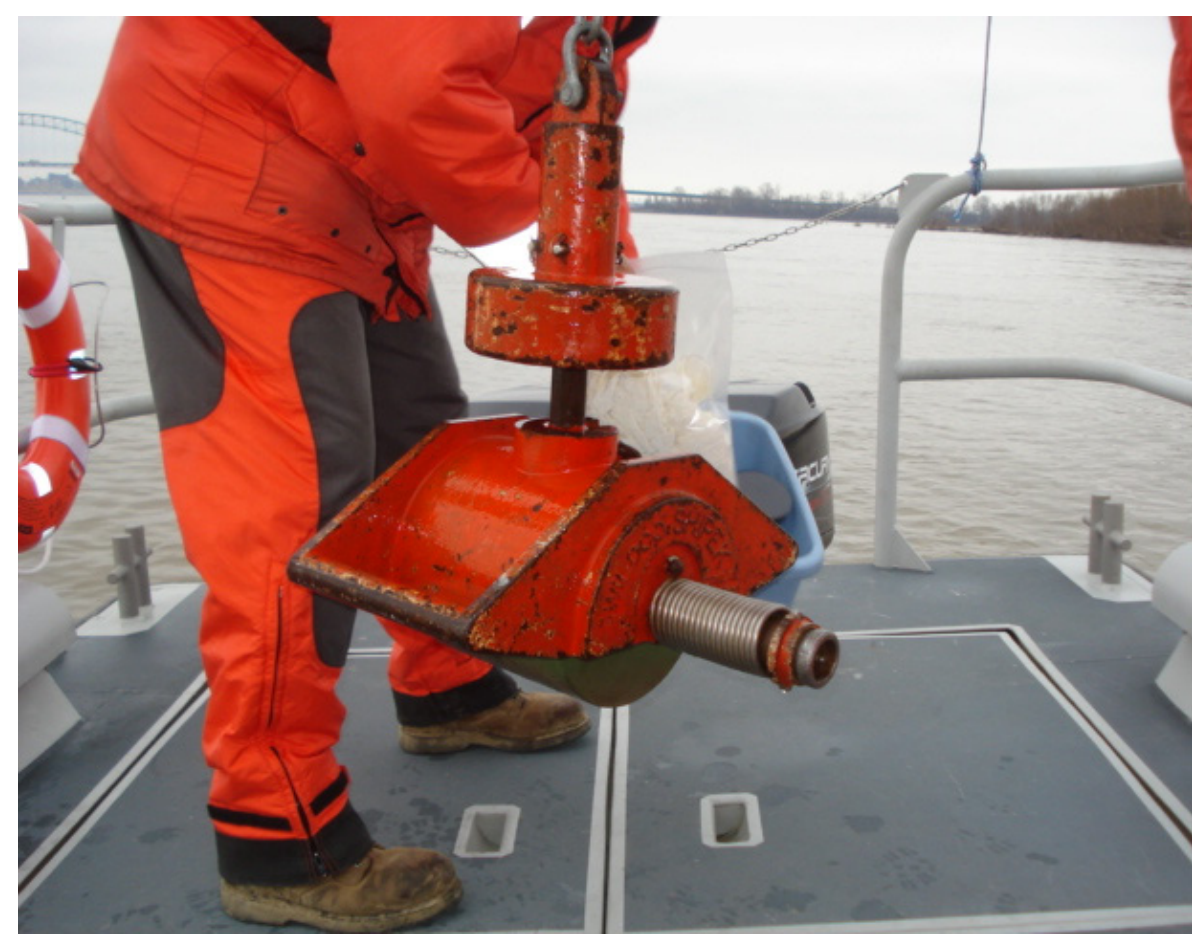

Preparing to collect bed-sediment sample from the Shipek grab sampler (Photograph by Daniel M. Wagner, U.S. Geological Survey). 

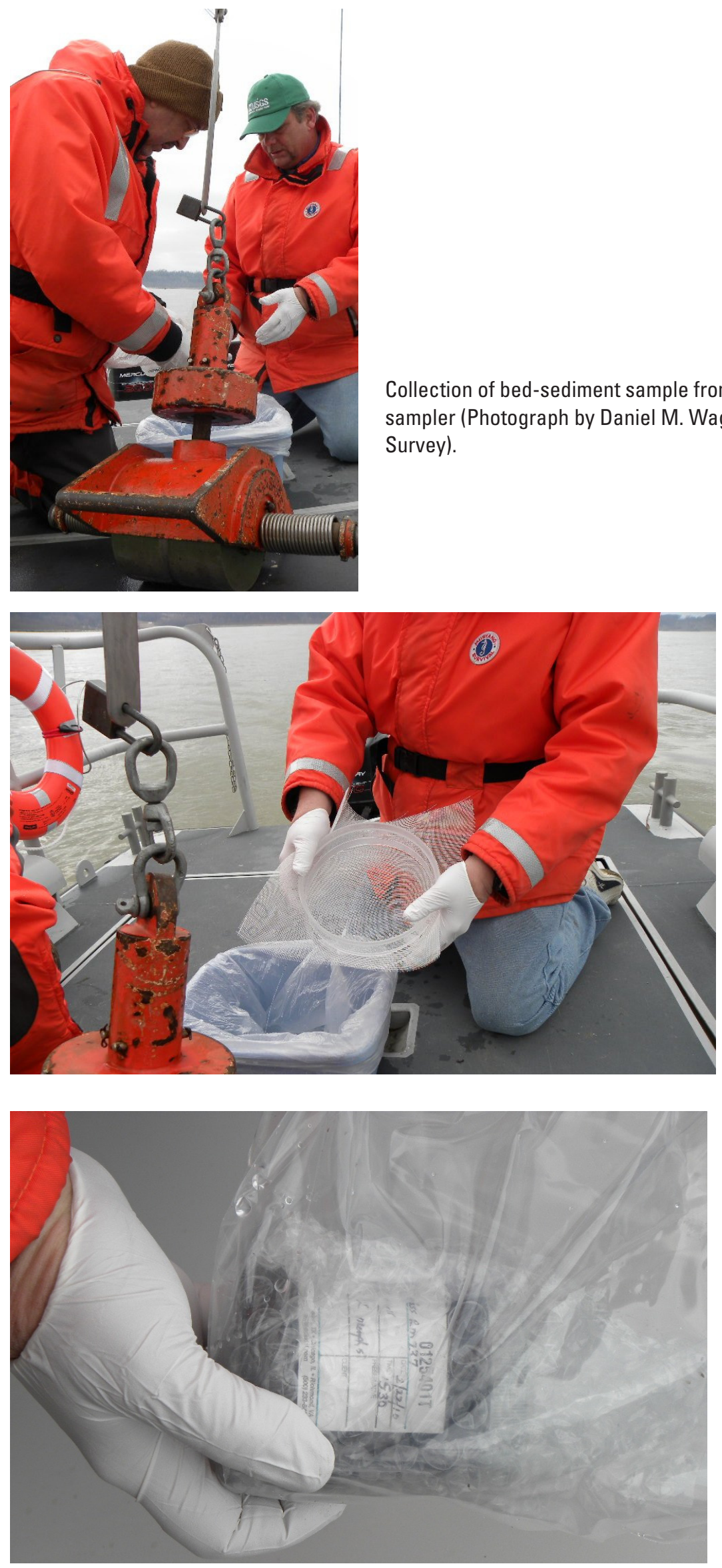

Collection of bed-sediment sample using 2-millimeter nylon sieve (Photograph by Daniel M. Wagner, U.S. Geological Survey).
Packaging of bed-sediment sample (Photograph by Daniel M. Wagner, U.S. Geological Survey). 

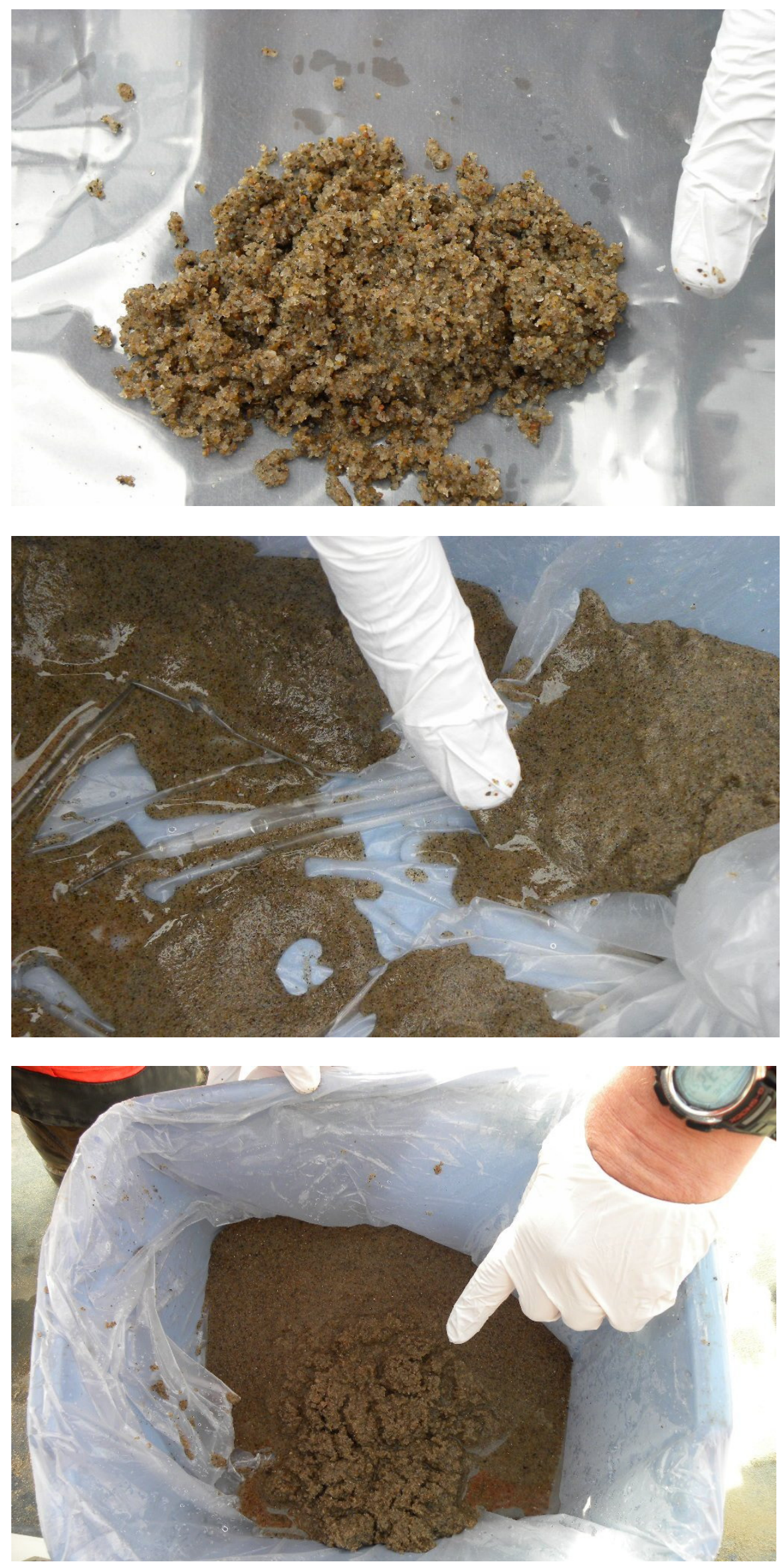

Bed-sediment sample collected at MISS-RM737 (Photograph by Daniel M. Wagner, U.S. Geological Survey).

Bed-sediment sample collected at MISS-RM773 (Photograph by Daniel M. Wagner, U.S. Geological Survey).

Bed-sediment sample collected at MISS-RM790 (Photograph by Daniel M. Wagner, U.S. Geological Survey). 
Appendix 2. Chain of custody forms used by U.S. Geological Survey laboratories and TestAmerica Laboratory, Inc.

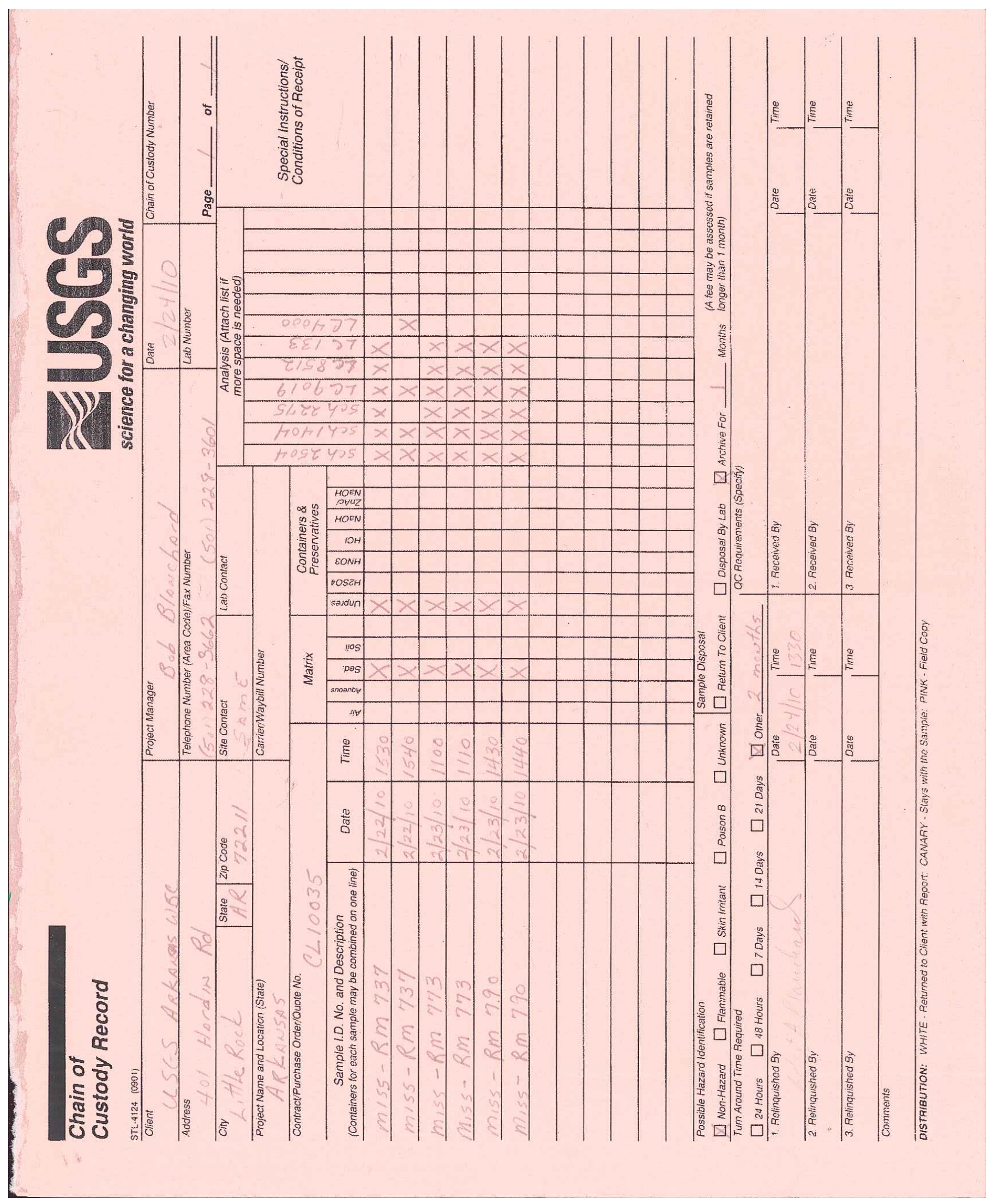




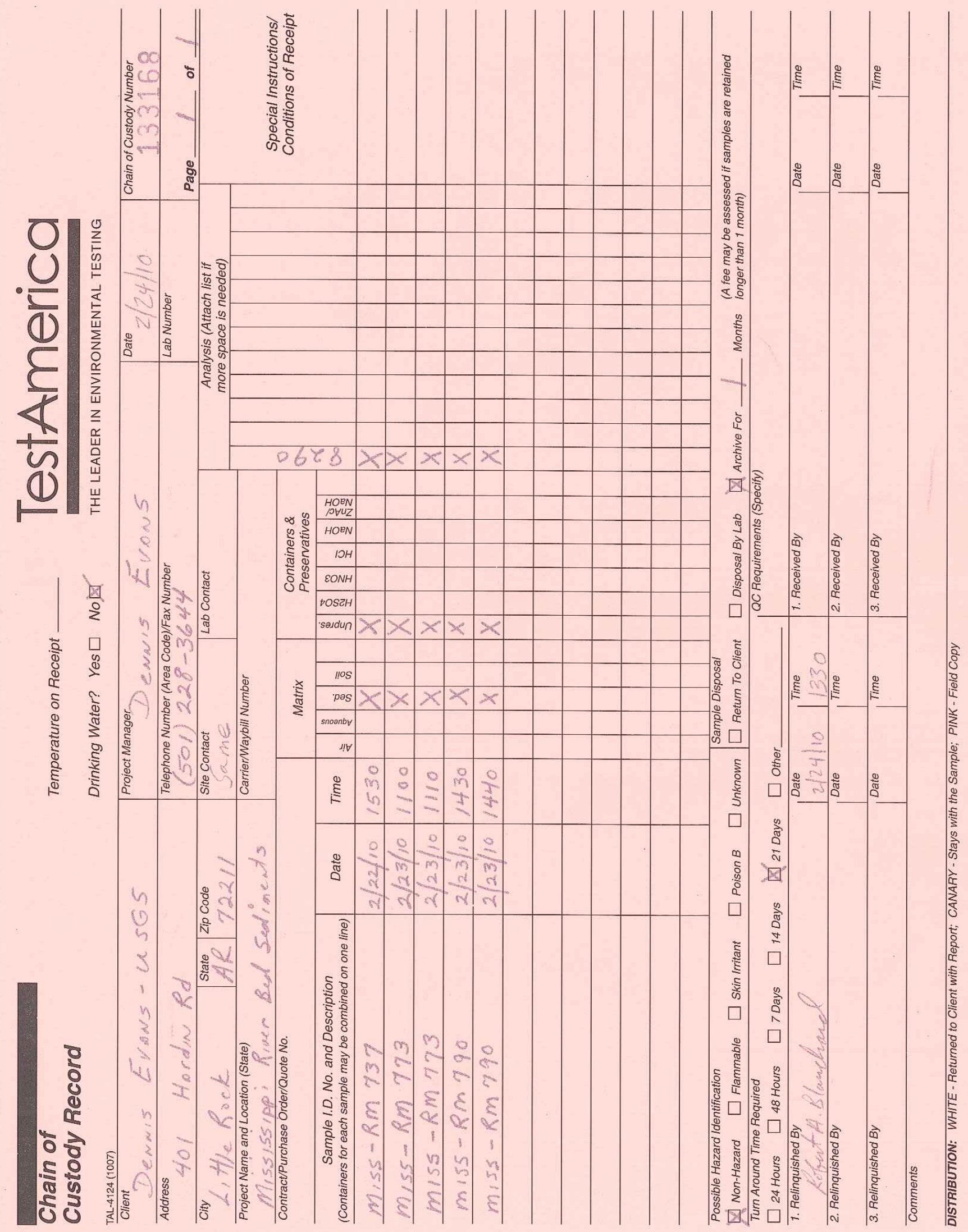


Publishing support provided by:

Lafayette Publishing Service Center

For more information concerning the research described in the report:

U.S. Geological Survey

Arkansas Water Science Center

401 Hardin Road

Little Rock, AR 72211-3528

(501) 228-3600

http://ar.water.usgs.gov 


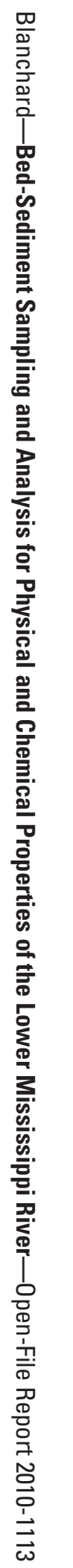

